\title{
Virology as biosystematics: towards understanding the viral infection biology
}

\section{Masako Nomaguchi and Akio Adachi*}

Department of Microbiology, Institute of Health Biosciences, The University of Tokushima Graduate School, Tokushima, Japan

*Correspondence: adachi@basic.med.tokushima-u.ac.jp

Large numbers of virus species exist in the realm of nature, and are now classified into distinct sub-groups based on their biochemical and biological characteristics (Knipe et al., 2007). Viruses are unique in their genomic composition, nucleocapsid/ virion morphology, replication strategy, and/or target host. Even though viruses represent the smallest entity encoding a genetic program and are strictly dependent on hosts for their replication, they adapt themselves in a species-specific and dexterous manner to infect or persist in a wide variety of living things. In the course of interaction with hosts, viruses somehow find ecological niches to prosper their progenies. By studying how viruses interact with their respective hosts, we have learned much about life itself in the past hundred years. On the other hand, viral infections in host individuals may sometimes result in the diseases with visible symptoms. Although viruses are often coexistent with hosts, they can cause fatal infectious diseases in extraordinary cases. We also have taken many important lessons from the virally caused illness.

The mission of research in virology today is to understand completely and systemically the biology and molecular biology of virus/host interaction. We virologists thus can contribute to the progress of life science and to the development of medical science. To achieve this aim, it is essentially necessary to integrate the concepts and methodologies of various scientific fields such as molecular/population genetics, biochemistry, genomics, epi-genomics, proteomics, transcriptomics, metabolomics, bioinformatics, and computational science into the biosystematics. Virology in nature is a multi-disciplinary affair. A typical and good example of this research flow is the history of studies on recently emerged human immunodeficiency viruses type 1 and 2 (HIV-1 and HIV-2) (Ho and Bieniasz, 2008). Highly specialized scientists of various fields have worked together and extensively to obtain fundamental knowledge on the HIV-1 virus and its interaction with humans, the only host with symptoms of disease, which led to the discovery of HIV-1 as the initial pathogen of human acquired immunodeficiency syndrome (AIDS) (Barre-Sinoussi et al., 1983). As a result of this multi-disciplinary approach to research, much is currently known about both basic as well as clinical aspects of HIV-1 and AIDS. The molecular basis for virus replication in target cells has been largely clarified, and drugs effective against the virus have been generated (Ho and Bieniasz, 2008). However, due to lack of appropriate animal model systems, studies aimed at elucidating viral events in vivo and, consequently, the discovery of more effective anti-viral strategies have been greatly hampered (Nomaguchi et al., 2008). Noteworthy, trials to develop anti-viral vaccines have been unsuccessful thereby underscoring the need for more suitable primate model research to answer basic questions about HIV-1 in vivo (Hayden, 2008; Watkins et al., 2008). In our laboratory, for instance, efforts have been made to generate a new class of HIV-1s that are tropic and pathogenic for macaque monkeys (Kamada et al., 2006; Igarashi et al., 2007; Nomaguchi et al., 2008). When successful, these viruses will provide the opportunity, not possible with currently available simian immunodeficiency virus (SIV) and SIV/HIV-1 chimeric viruses, to analyze the function of multiple HIV-1 genes in non-human primate species frequently used for experimental viral infections.

In conclusion, virologists today must study viruses multilaterally. With the help of various specialists if necessary, they are required to analyze viruses and their interactions with hosts comprehensively and systemically. Only with such a multi-disciplinary experimental approach, will we be able to better understand how viruses work and in the position to educate and inform the lay public about the importance of our science to the well-being of mankind.

\section{REFERENCES}

Barre-Sinoussi, F., Chermann, J. C., Rey, F., Nugeyre, M. T., Chamaret, S., Gruest, J., Dauguet, C., Axler-Blin, C., Vezinet-Brun, F., Rouzioux, C., Rozenbaum, W., and Montagnier, L. (1983). Isolation of a T-lymphotropic retrovirus from a patient at risk for acquired immune deficiency syndrome (AIDS). Science 220, 868-871.

Hayden, E. C. (2008). US plans more primate research. Nature 453, 439.

Ho, D. D., and Bieniasz, P. D. (2008). HIV-1 at 25. Cell 133, 561-565.

Igarashi, T., Iyengar, R., Byrum, R. A., Buckler-White, A., Dewar, R. L., Buckler, C. E., Lane, H. C., Kamada, K., Adachi, A., and Martin, M. A. (2007). Human immunodeficiency virus type 1 derivative with $7 \%$ simian immunodeficiency virus genetic content is able to establish infections in pig-tailed macaques. J. Virol. 81, 11549-11552.

Kamada, K., Igarashi, T., Martin, M. A., Khamsri, B., Hatcho, K., Yamashita, T., Fujita, M., Uchiyama, T., and Adachi, A. (2006). Generation of HIV-1 derivatives that productively infect macaque monkey lymphoid cells. Proc. Natl. Acad. Sci. U.S.A. 103, 16959-16964.

Knipe, D. M., Howley, P. M., Griffin, D. E., Lamb, R. A., Martin, M. A., Roizman, B., and Straus, S. E. (eds) (2007). Fields Virology 5th Edn. Philadelphia, PA: Lippincott Williams and Wilkins.

Nomaguchi, M., Doi, N., Kamada, K., and Adachi, A. (2008). Species barrier of HIV-1 and its jumping by virus engineering. Rev. Med. Virol. 18, 261-275.

Watkins, D. I., Burton, D. R., Kallas, E. G., Moore, J. P., and Koff, W. C. (2008). Nonhuman primate models and the failure of the Merck HIV-1 vaccine in humans. Nat. Med. 14, 617-621.

Received: 09 May 2010; accepted: 12 May 2010; published online: 20 July 2010.

Citation: Nomaguchi M and Adachi A (2010) Virology as biosystematics: towards understanding the viral infection biology. Front. Microbio. 1:2. doi: 10.3389/ fmicb.2010.00002

This article was submitted to Frontiers in Virology, a specialty of Frontiers in Microbiology.

Copyright (c) 2010 Nomaguchi and Adachi. This is an open-access article subject to an exclusive license agreement between the authors and the Frontiers Research Foundation, which permits unrestricted use, distribution, and reproduction in any medium, provided the original authors and source are credited. 